\title{
The regulation of stearoyl-CoA desaturase gene expression is tissue specific in chickens
}

\author{
Sami Dridi, Mohammed Taouis ${ }^{1}$, Arieh Gertler ${ }^{2}$, Eddy Decuypere and Johan Buyse \\ Laboratory of Physiology, Immunology, and Genetics of Domestic Animals, Catholic University of Leuven, KU Leuven, 3001 Heverlee, Belgium \\ ${ }^{1}$ University Paris sud, bat 447, 91405 Orsay Cedex, France \\ ${ }^{2}$ Faculty of Agriculture, Institute of Biochemistry, Food Science and Nutrition, The Hebrew University, Rehovot 76100, Israel \\ (Requests for offprints should be addressed to S Dridi; Email: sami.dridi@biw.kuleuven.be)
}

\begin{abstract}
Emerging evidence suggests a potential role of stearoyl-CoA desaturase (SCD)-1 in the control of body weight and energy homeostasis. The present study was conducted to investigate the effects of several energy balance-related factors (leptin, cerulenin, food deprivation, genotype, and gender) on SCD gene expression in chickens. In experiment 1, 6-week-old female and male broiler chickens were used. In experiment 2 , two groups of 3-week-old broiler chickens were continuously infused with recombinant chicken leptin $(8 \mu \mathrm{g} / \mathrm{kg} / \mathrm{h})$ or vehicle for $6 \mathrm{~h}$. In experiment 3 , two groups of 2 -week-old broiler chickens received i.v. injections of cerulenin $(15 \mathrm{mg} / \mathrm{kg})$ or vehicle. In experiment 4 , two broiler chicken lines (fat and lean) were submitted to two nutritional states (food deprivation for 16 or $24 \mathrm{~h}$ and feeding ad libitum). At the end of each experiment, tissues were collected for analyzing $S C D$ gene expression. Data from experiment 1 showed that SCD is ubiquitously expressed in chicken tissues with highest levels in the proventriculus followed by the ovary,
\end{abstract}

hypothalamus, kidney, liver, and adipose tissue in female, and hypothalamus, leg muscle, pancreas, liver, and adipose tissue in male. Female chickens exhibited significantly higher SCD mRNA levels in kidney, breast muscle, proventriculus, and intestine than male chickens. However, hypothalamic $S C D$ gene expression was higher in male than in female $(P<0 \cdot 05)$. Leptin increased SCD gene expression in chicken liver $(P<0 \cdot 05)$, whereas cerulenin decreased SCD mRNA levels in muscle. Both leptin and cerulenin significantly reduced food intake $(P<0 \cdot 05)$. Food deprivation for either 16 or $24 \mathrm{~h}$ decreased the hepatic SCD gene expression in fat line and lean line chickens compared with their fed counterparts $(P<0 \cdot 05)$. The hypothalamic SCD mRNA levels were decreased in both lines only after $24 \mathrm{~h}$ of food deprivation $(P<0 \cdot 05)$. In conclusion, SCD is ubiquitously expressed in chickens and it is regulated by leptin, cerulenin, nutritional state, and gender in a tissue-specific manner.

Journal of Endocrinology (2007) 192, 229-236

\section{Introduction}

Stearoyl-CoA desaturase (SCD) is an integral membrane protein of the endoplasmic reticulum that catalyzes the ratelimiting step in the biosynthesis of monounsaturated fatty acids from saturated fatty acids (Heineman \& Ozols 2003, Miyazaki \& Ntambi 2003). SCD induces, in conjunction with NADPH-cytochrome $b 5$ reductase and cytochrome $b 5$, a cis-configuration double bond into its substrates, palmitic and stearic acid, to generate the products, palmitoleic and oleic acid (Enoch et al. 1976). These monounsaturated fatty acids are used as substrates for the synthesis of triglycerides, wax esters, cholesteryl esters, and membrane phospholipids.

Four SCD isoforms have been characterized in the mice (Ntambi et al. 1988, Kaestner et al. 1989, Zheng et al. 2001, Miyazaki et al. 2003). These isoforms displayed similar desaturation activities towards stearoyl-CoA and palmitoylCoA, but have different tissue distributions. Mouse SCD-1 (mSCD-1) is expressed in a broad range of tissues and at high levels in liver, adipose tissue, preputial gland, and Harderian gland. Highest mSCD-2 expression was detected in brain and Harderian gland, while mSCD-3 expression is limited to Harderian gland. Mouse SCD-4 appears to be heart specific. Two SCD isoforms have been identified in human (hSCD-1 and -5; Zhang et al. 1999, Wang et al. 2005) and in rat (rSCD-1 and-2; Mihara 1990). Human SCD-5 was abundantly expressed in brain and pancreas (Wang et al. 2005). In birds, one SCD isoform (SCD) has been, so far, identified and cloned (GenBank accession number X60465) and very little is known about its tissue distributions and regulation (Lefevre et al. 1999, 2001).

Increasing evidence suggests that SCD-1 plays a crucial role in lipid metabolism and body weight control in mammals. Indeed, asebia mice (homozygous for a naturally occurring mutation that results in the lack of SCD-1 expression; Zheng et al. 1999) and SCD-1 knockout mice are lean and hypermetabolic (Ntambi et al. 2002). Recently, SCD-1 was found to be a major peripheral target of leptin (Cohen et al. 2002), a key regulator of energy homeostasis and satiety. 
Leptin reduces liver SCD-1 mRNA expression as well as its enzymatic activity, which contributes to food intake reduction and weight loss in mice (Cohen et al. 2002). ob/ ob mice with SCD-1 mutations were significantly less obese than ob/ob controls and had markedly increased energy expenditure with reduced triglyceride storage in liver (Cohen et al. 2002). Thus, SCD-1 is an important component of the novel metabolic response to leptin signaling. Such studies are currently lacking in birds (non mammalian species) which manifest some peculiarities: (1) broiler chickens were selected for rapid growth and high food intake and are prone to obesity (Griffin \& Goddard 1994); (2) leptin is expressed not only in adipose tissue, but also in liver in chickens (Taouis et al. 1998, Ashwell et al. 1999), while it is mainly expressed in adipose tissue in mammals (Zhang et al. 1994); (3) the mechanism of leptin action on food intake regulation in chickens is quite different from that described in mammals (Dridi et al. 2005a); and (4) as in human, lipogenesis occurs essentially in the liver of chickens (Leveille et al. 1968), however, in rodents, lipogenesis occurs in both adipose tissue and liver (Blair et al. 1991). Therefore, chicken is an interesting model for understanding appetite, satiety, and lipid metabolism at molecular levels.

The present study aimed, first, to determine the expression of SCD in different tissues of female and male broiler chickens; secondly, to investigate the effects of leptin and cerulenin on food intake and SCD gene expression in chicken liver, hypothalamus, and muscle; and finally, to assess whether food deprivation and genetic selection for abdominal fat pad size affect SCD gene expression in these metabolically important tissues.

\section{Materials and Methods}

\section{Animals}

Experiments were conducted in accordance with the directives of the European community (86/609/EEC) on the care and use of laboratory animals and the experimental protocols were approved by the K U Leuven Ethical Committee for Animal Experiments.

\section{Experiment 1: tissue distribution of SCD gene expression in male and female broiler chickens}

Male and female broiler (Cobb 500 strain) chickens (Avibel, Halle-Zoersel, Belgium) of 6 weeks of age (1765 and $2665 \mathrm{~g}$ for female and male respectively) were kept in floor pens under a $14 \mathrm{~h}$ light: $10 \mathrm{~h}$ darkness cycle. Chickens were supplied with food (Table 1) and water available ad libitum. Three chickens from each gender were killed by cervical dislocation and tissues (adipose tissue, lung, liver, kidney, hypothalamus, heart, leg and breast muscle, pancreas, gizzard, proventriculus, intestine, testis, and ovary) were removed, immediately snap frozen in liquid nitrogen, and stored at $-80{ }^{\circ} \mathrm{C}$ until use.
Table 1 Diet composition and calculated analysis

Experiment 1, 2 and 3

Experiment 4

\begin{tabular}{|c|c|c|}
\hline \multicolumn{3}{|l|}{ Ingredients $(\mathrm{g} / \mathrm{kg})$} \\
\hline Wheat & $350 \cdot 2$ & $384 \cdot 5$ \\
\hline Yellow maize & $150 \cdot 0$ & $100 \cdot 0$ \\
\hline French peas & $150 \cdot 0$ & $120 \cdot 0$ \\
\hline $\begin{array}{l}\text { Soybean meal, } 500 \text { g crude } \\
\text { protein } / \mathrm{kg}\end{array}$ & $125 \cdot 0$ & $34 \cdot 0$ \\
\hline Full fat soy & $100 \cdot 0$ & $100 \cdot 0$ \\
\hline $\begin{array}{l}\text { Sunflower meal, } 280 \text { g crude } \\
\text { protein } / \mathrm{kg}\end{array}$ & - & $5 \cdot 0$ \\
\hline Oilcake meal & $20 \cdot 0$ & $55 \cdot 0$ \\
\hline Rapeseed meal & - & $26 \cdot 0$ \\
\hline Animal meal & $65 \cdot 0$ & $105 \cdot 0$ \\
\hline Fish meal & $10 \cdot 0$ & $10 \cdot 0$ \\
\hline Animal fat & $12 \cdot 0$ & $18 \cdot 0$ \\
\hline Fatty acids & - & $10 \cdot 0$ \\
\hline Limestone & $2 \cdot 4$ & - \\
\hline Methionine & $2 \cdot 3$ & $1 \cdot 3$ \\
\hline Lysine & $2 \cdot 1$ & $0 \cdot 7$ \\
\hline Choline & $0 \cdot 5$ & $0 \cdot 5$ \\
\hline Common salt & $1 \cdot 5$ & - \\
\hline Vitamin and mineral premix ${ }^{a}$ & $4 \cdot 0^{\mathrm{b}}$ & $4 \cdot 0^{\circ}$ \\
\hline Wheat enzyme preparation & $4 \cdot 0$ & $4 \cdot 0$ \\
\hline Sodium bicarbonate & - & $1 \cdot 0$ \\
\hline Sepiolite & - & $20 \cdot 0$ \\
\hline \multicolumn{3}{|l|}{ Calculated composition $(\mathrm{g} / \mathrm{kg})$} \\
\hline Crude protein & $222 \cdot 2$ & $214 \cdot 2$ \\
\hline Crude fiber & $29 \cdot 7$ & $31 \cdot 5$ \\
\hline Crude fat & $58 \cdot 2$ & $81 \cdot 3$ \\
\hline Starch and sugars & $428 \cdot 4$ & $408 \cdot 7$ \\
\hline Moisture & $117 \cdot 9$ & $110 \cdot 0$ \\
\hline Lysine & $11 \cdot 0$ & $10 \cdot 4$ \\
\hline Methionine and cystine & $8 \cdot 8$ & $7 \cdot 6$ \\
\hline Tryptophan & $2 \cdot 2$ & $2 \cdot 1$ \\
\hline Threonine & $7 \cdot 1$ & $6 \cdot 7$ \\
\hline Choline & $1 \cdot 5$ & $1 \cdot 5$ \\
\hline Essential fatty acids & $19 \cdot 9$ & $24 \cdot 3$ \\
\hline Potassium & - & $7 \cdot 1$ \\
\hline Calcium & $9 \cdot 0$ & $7 \cdot 5$ \\
\hline $\mathrm{P}$ (total) & $7 \cdot 0$ & $6 \cdot 0$ \\
\hline $\mathrm{P}$ (available) & $4 \cdot 9$ & $4 \cdot 3$ \\
\hline Chloride & $2 \cdot 6$ & $2 \cdot 3$ \\
\hline Sodium & $1 \cdot 5$ & $1 \cdot 9$ \\
\hline $\begin{array}{l}\text { Metabolizable energy } \\
(\mathrm{MJ} / \mathrm{kg})\end{array}$ & $12 \cdot 1$ & $12 \cdot 6$ \\
\hline L-carnitine & $17 \cdot 8$ & $22 \cdot 9$ \\
\hline
\end{tabular}

a,b Vitamin and mineral premix provided per kilogram diet: retinol acetate, $3800 \mu \mathrm{g}$; cholecalciferol, $60 \mu \mathrm{g}$; $\alpha$-tocopherol, $30 \mathrm{mg}$; menadione, $1.5 \mathrm{mg}$; thiamin, $1.5 \mathrm{mg}$; riboflavin, $4 \mathrm{mg}$; pyridoxine, $2 \mathrm{mg}$; cobalamin, $20 \mu \mathrm{g}$; niacin, $30 \mathrm{mg}$; biotin, $70 \mu \mathrm{g}$; folic acid, $1 \mathrm{mg}$; pantothenic acid, $10 \mathrm{mg}$; $\mathrm{Mn}$, $80 \mathrm{mg}(\mathrm{MnO}) ; \mathrm{Fe}, 90 \mathrm{mg}\left(\mathrm{FeSO}_{4} \cdot \mathrm{H}_{2} \mathrm{O}\right) ; \mathrm{Cu}, 22 \mathrm{mg}\left(\mathrm{CuSO}_{4} \cdot 5 \mathrm{H}_{2} \mathrm{O}\right) ; \mathrm{Co}$,

$0 \cdot 2 \mathrm{mg}\left(\mathrm{CoSO}_{4}\right) ; \mathrm{I}, 0.8 \mathrm{mg}(\mathrm{KI}) ; \mathrm{Se}, 0 \cdot 2 \mathrm{mg}\left(\mathrm{Na}_{2} \mathrm{SeO}_{3}\right) ; \mathrm{Zn}, 50 \mathrm{mg}(\mathrm{ZnO})$. a, $\mathrm{V}$ itamin and mineral premix provided per kilogram diet: the same as 'a, $\mathrm{b}$ ' except for retinol acetate, $3100 \mu \mathrm{g}$; menadione, $2 \mathrm{mg}$; thiamin, $2 \mathrm{mg}$; cobalamin, $120 \mu \mathrm{g}$; biotin, $50 \mu \mathrm{g}$; l, $0.54 \mathrm{mg}(\mathrm{KI})$.

\section{Experiment 2: leptin treatment}

Male broiler chicks (Ross 308), which were 1 day old, were purchased from Avibel and reared in floor pens until 2 weeks of age, at which time the birds were transferred to individual cages and the diet in Table 1 was fed. After 3 days of adaptation, birds were weighed and cannulated in the brachial artery (Huybrechts et al. 1992) under local anesthesia (xylocaine). The chickens were allowed to recover and 
adapt during 4 more days. Before the infusion experiment, the chickens were divided into two homogenous weightmatched groups $(n=5$, mean body weight was $1000 \mathrm{~g})$ and food deprived for $2 \mathrm{~h}$ in order to increase their appetite. The mini pump (Syringe pump series, Model 22, Harvard apparatus, Holliston, MA, USA) infused recombinant chicken leptin prepared as previously described (Raver et al. $1998 ; 8 \mu \mathrm{g} / \mathrm{kg} / \mathrm{h}$ ) or saline at a constant rate of $3 \mathrm{ml} / \mathrm{h}$ during $6 \mathrm{~h}$ and food intake was recorded after the treatment $(6 \mathrm{~h})$. Birds were killed by cervical dislocation and tissues (hypothalamus, liver, and leg muscle) were removed, snap frozen in liquid nitrogen, and stored at $-80{ }^{\circ} \mathrm{C}$ until use.

\section{Experiment 3: cerulenin administration}

Broiler chickens (Ross 308), which were 1 day old, were purchased from a commercial hatchery (Avibel) and reared on floor pen until 1 week of age, at which time the birds were transferred to individual cages and provided with individual feeders and drinking nipples. Food (Table 1) and water were consumed ad libitum and the lighting schedule provided $14 \mathrm{~h}$ of light per day. After 1 week of adaptation, birds were divided into two homogenous weight- (267 g) and food intake-matched groups $(n=4)$, and food deprived for $2 \mathrm{~h}$ in order to increase their appetite. Each bird received an i.v. injection (at 0,4 , and $24 \mathrm{~h}$ ) of $15 \mathrm{mg} / \mathrm{kg}$ cerulenin (Sigma) or equal volume of vehicle $(10 \%$ dimethyl sulfoxide in Roswell Park Memorial Institute Medium 1640 medium). Cumulative food intake was measured after $28 \mathrm{~h}$ and tissues (hypothalamus, liver, and leg muscle) were removed, frozen in liquid nitrogen, and stored at $-80^{\circ} \mathrm{C}$ until use.

\section{Experiment 4: genotype and nutritional status}

In order to assess whether SCD gene expression is regulated by nutritional state and genotype, two broiler chicken lines were used. These two lines were established by long-term divergent selection for ratio of abdominal fatness to live weight, after which the fat line (FL) had about 1.5- to 2-fold abdominal fat weight of the lean line (LL) at 9 weeks of age (Leclercq et al. 1980). Chickens (male) of each line (mean body weights were 2400 and $2230 \mathrm{~g}$ for FL and LL respectively) were kept in conventional floor pens, fed ad libitum with a balanced diet (Table 1), and exposed to a daily $14 \mathrm{~h}$ light period. At 9 weeks of age, chickens were submitted to two different nutritional states: food deprivation for 16 or $24 \mathrm{~h}$ and feeding ad libitum $(n=3)$. After blood sampling and cervical dislocation, tissues (hypothalamus, liver, and leg muscle) were quickly removed, frozen in liquid nitrogen, and stored at $-80^{\circ} \mathrm{C}$ until use.

\section{Reverse transcription and PCR (RT-PCR)}

Total RNA was extracted from $100 \mathrm{mg}$ tissue using the Trizol reagent (Invitrogen) according to the manufacturer's protocol. RNA integrity was assessed via 1\% agarose gel electrophoresis and RNA concentrations and purity were determined for each sample spectrophotometrically using UV absorbance (260/280). Total RNA $(1 \mu \mathrm{g})$ was reverse transcribed and subjected to PCR in the presence of two pairs of primers. The first one was specific to chicken SCD (GenBank Accession number X60465): sense 5'-TCCCTTCTGCAAAGATCCAG-3' and antisense 5'-AGCACAGCAACACCACTGAG-3', flanking a $402 \mathrm{bp}$ region. The second pair of primers was specific for chicken ribosomal 18S RNA (internal control; for sequences, see Dridi et al. 2005a). PCR was performed in $50 \mu \mathrm{l}$ solution containing $2 \mu \mathrm{l} \mathrm{RT}$ product, $1 \mathrm{U}$ Taq DNA polymerase (Roche Diagnostic), $0.1 \mathrm{mmol} / 1 \mathrm{dNTP}$ mixture, and $10 \mathrm{pmol}$ of each forward and reverse primer. Twenty-five cycles ( 35 for characterization and probe preparation) were performed, each cycle consisting of denaturation $\left(94^{\circ} \mathrm{C}, 30 \mathrm{~s}\right)$, annealing $\left(58^{\circ} \mathrm{C}, 30 \mathrm{~s}\right)$, and elongation $\left(72^{\circ} \mathrm{C}, 1 \mathrm{~min}\right)$ except for the first cycle in which denaturation was for $2 \mathrm{~min}$ and the last cycle in which the extension time was for $10 \mathrm{~min}$. The number of cycles used for each gene was in the linear amplification range.

\section{Probe labeling and Southern blot analysis}

The amplified fragments were separated on a low melting point agarose gel (1\%) and the appropriate bands were cut out, purified using Qiaquick gel extraction kit protocol (Qiagen) and stored at $-20^{\circ} \mathrm{C}$. The cDNA fragments were cloned in the pPCR Script Amp SK (+) cloning vector using the pPCR Script Amp cloning kit (Stratagene) and automatically sequenced using an Applied Biosystems automated sequencer. The cloned fragments (25-30 ng) were labeled by random priming with $\left(\alpha-{ }^{32} \mathrm{P}\right) \mathrm{dCTP}$ (Feinberg \& Vogelstein 1983). The amplified PCR products were transferred to nylon membrane using a vacuum blotting apparatus (Amersham Biosciences) and cross-linked by u.v. irradiation and baked at $80^{\circ} \mathrm{C}$ for 20-30 min. Membranes were hybridized with heat denatured ${ }^{32} \mathrm{P}$-labeled DNA probes, prepared as described earlier, at $42{ }^{\circ} \mathrm{C}$ overnight. During the following day, the membranes were rinsed twice with $1 \times \mathrm{SSC}, 0 \cdot 1 \% \mathrm{SDS}$ at $55^{\circ} \mathrm{C}$. Each wash was for $20 \mathrm{~min}$ and then membranes were subjected to storage phosphor autoradiography cassette. Hybridization signals were quantified using phosphorimagery (Bio-Imaging Analyzer BAS 1000 Mac BAS, Fujix (Fuji, Tokyo, Japan), TINA software, version 2.09, Belgium).

\section{Plasma leptin measurement}

Circulating leptin concentrations were determined by RIA (multi-species leptin RIA kit, Linco Research Co. Mo, USA). The RIA has been validated for chicken leptin (Dridi et al. 2000a). Samples were assayed in a single assay and the intraassay coefficient of variation was $6 \cdot 3 \%$.

\section{Statistical analysis}

The data were analyzed using the Student's unpaired $t$-test except the data from experiments 1 and 4, which were 
analyzed by two-factor ANOVA with tissue and gender (experiment 1), and genotype and nutritional state (experiment 4) as classification variables. If ANOVA revealed significant effects, the means were compared by StudentNewman-Keuls multiple range test using the general linear model procedure of Statistical Analysis System (SAS) software (SAS Institute 2000, Version 8.1). Differences were considered significant at $P<0 \cdot 05$.

\section{Results}

Tissue distribution of SCD gene expression in male and female chickens

SCD gene was expressed in all tissues examined in female and male broiler chickens. Proventriculus was found to contain the highest amount of SCD mRNA, followed by ovary, kidney, hypothalamus, liver, and adipose tissue in female chickens. However, in males, the highest levels were observed in hypothalamus, leg muscle, pancreas, liver, adipose tissue, and testis. Interestingly, when tissues from the two genders were plotted together, females exhibited significantly $(P<0 \cdot 05)$ higher levels of SCD mRNA in kidney $(68 \%)$, breast muscle $(111 \%)$, proventriculus $(212 \%)$, and intestine (320\%) compared with the male (Fig. 1). In contrast, hypothalamic SCD gene expression was significantly higher in male than in female chickens $(39 \% ; P<0 \cdot 05)$.

\section{Effect of leptin on chicken SCD gene expression}

Recombinant chicken leptin increased plasma leptin levels (23-fold; $P<0.0001)$ and reduced cumulative food intake $(51 \% ; P<0.05)$ as compared with the control (Table 2). Despite the inhibition of food intake, leptin significantly induced the expression of $S C D$ gene in chicken liver as compared with the control $(29 \% ; P<0 \cdot 05$; Fig. 2). However, the SCD mRNA levels in the hypothalamus and muscle were not affected by this treatment $(1 \cdot 13 \pm 0 \cdot 14$ vs $1 \cdot 00 \pm 0 \cdot 05$ for hypothalamus, and $1 \cdot 10 \pm 0 \cdot 10$ vs $0 \cdot 95 \pm 0 \cdot 10$ for muscle of the control- and leptin-treated group respectively; mean \pm s.E.M., $n=5$ ).

\section{Effect of cerulenin on chicken SCD gene expression}

Cerulenin treatment reduced the cumulative food intake by $22 \%(P<0 \cdot 01)$ and plasma leptin levels by $22 \cdot 5 \%(P=0 \cdot 3)$ relative to the control (Table 2 ). Cerulenin administration significantly reduced the expression of $S C D$ gene in muscle by $37 \%(P<0 \cdot 05$; Fig. 3$)$, but not in liver or hypothalamus $(0.82 \pm 0.13$ vs $0.95 \pm 0.08$ for hypothalamus, and $1.18 \pm$ $0 \cdot 19$ vs $1 \cdot 21 \pm 0 \cdot 05$ for liver of control- and cerulenin-treated group respectively; mean \pm s.E.M., $n=4$ ).

\section{Effect of genotype and nutritional state on chicken SCD gene expression}

Food deprivation for either 16 or $24 \mathrm{~h}$ significantly downregulated the hepatic SCD gene expression in FL by 52 and $52.5 \%$ respectively and in LL chickens by 43 and $34 \cdot 7 \%$ respectively compared with that of their ad libitum fed counterparts $(P<0 \cdot 05$; Fig. $4 \mathrm{~A}$ and $\mathrm{B})$. However, the hypothalamic SCD mRNA levels were significantly decreased by $17 \%$ for FL and $13.3 \%$ for LL chickens only after $24 \mathrm{~h}$ of food deprivation compared with ad libitum feeding state $(P<0 \cdot 05$; Fig. 5). In muscle, food deprivation for either 16 or $24 \mathrm{~h}$ did not affect the expression of SCD. Furthermore, independent of the nutritional state, SCD gene expression did not differ between the two lines in all tissues examined.

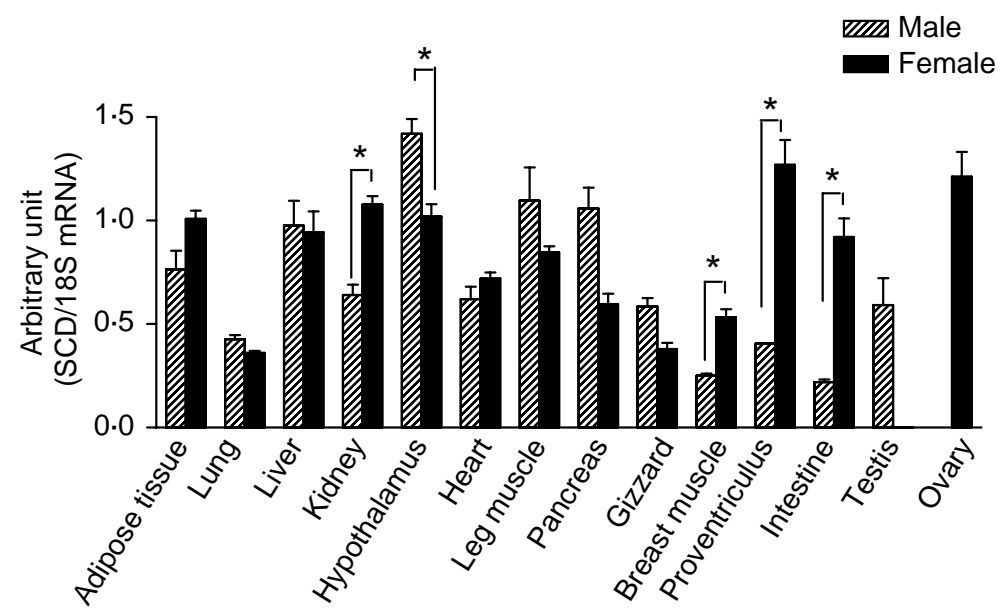

Figure 1 Relative quantity of SCD mRNA in different tissues of 6-week-old female and male broiler chickens. Values are means \pm S.E.M., $n=3$. *Different from the female, $P<0 \cdot 05$. 
Table 2 Effects of leptin and cerulenin treatments on cumulative food intake and plasma leptin levels in broiler chickens. Values are means \pm s.E.M.

\begin{tabular}{|c|c|c|}
\hline & Control group & Treated group \\
\hline \multicolumn{3}{|l|}{ Leptin treatment } \\
\hline Food intake (g/6 h) & $67 \cdot 1 \pm 9 \cdot 4$ & $32 \cdot 8 \pm 3 \cdot 9 *$ \\
\hline Plasma leptin levels (ng/ml) & $2 \cdot 68 \pm 0 \cdot 32$ & $61 \cdot 9 \pm 4 \cdot 7^{*}$ \\
\hline \multicolumn{3}{|c|}{ Cerulenin treatment } \\
\hline Food intake (g/28 h) & $85 \cdot 9 \pm 2 \cdot 4$ & $67 \cdot 0 \pm 1 \cdot 9 *$ \\
\hline Plasma leptin levels (ng/ml) & $1 \cdot 29 \pm 0 \cdot 26$ & $1 \cdot 00 \pm 0 \cdot 05$ \\
\hline
\end{tabular}

*Different from the control, $P<0 \cdot 05$.

\section{Discussion}

SCD is expressed in a wide range of tissues in broiler chickens. The expression of SCD gene is tissue- and genderdependent, corroborating previous studies in mammals (Lee et al. 1996, Chung et al. 2000, Zheng et al. 2001). The underlying mechanism(s) for these differences is unknown. It could be due to differences in fat deposition within tissues and/or levels of hormones, particularly sexual hormones. Estrogen administration induces SCD activity and causes a remarkable increase in plasma lipid and very low density lipoprotein production in avian species (Lippiello et al. 1979, Dashti et al. 1983). Several peroxisome proliferators induce $S C D$ gene expression differently in male than in female and this difference has been shown to be related to higher levels of testosterone in male (Kawashima et al. 1989). It is possible that other hormones known to be involved in lipid metabolism, such as leptin (Cohen et al. 2002), ghrelin (Theander-Carrillo et al. 2006), growth hormone, and

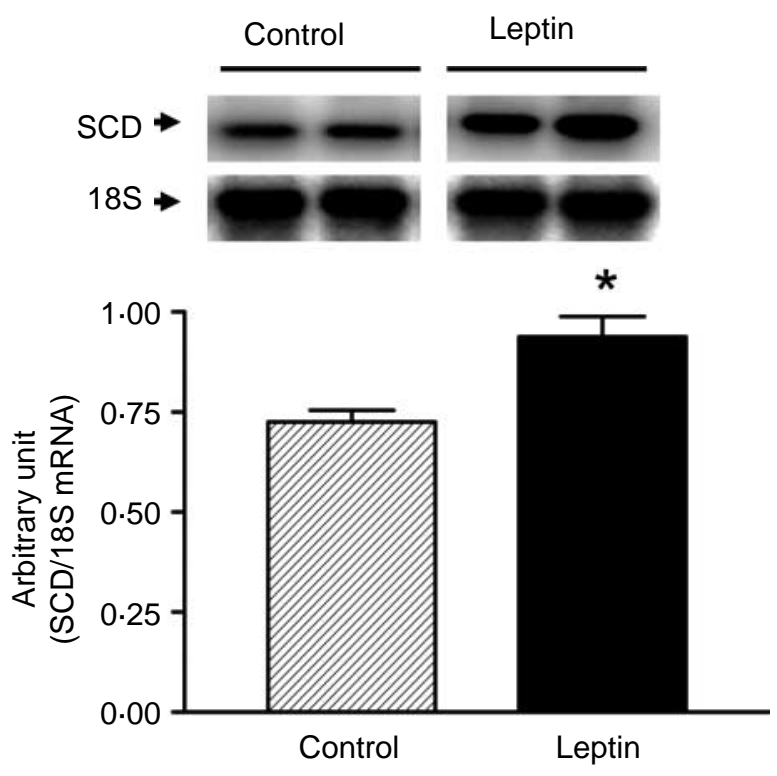

Figure 2 Effect of recombinant chicken leptin infusion on hepatic $S C D$ gene expression in 3-week-old broiler chickens. Values are means \pm S.E.M., $n=5$. *Different from the control, $P<0 \cdot 05$.

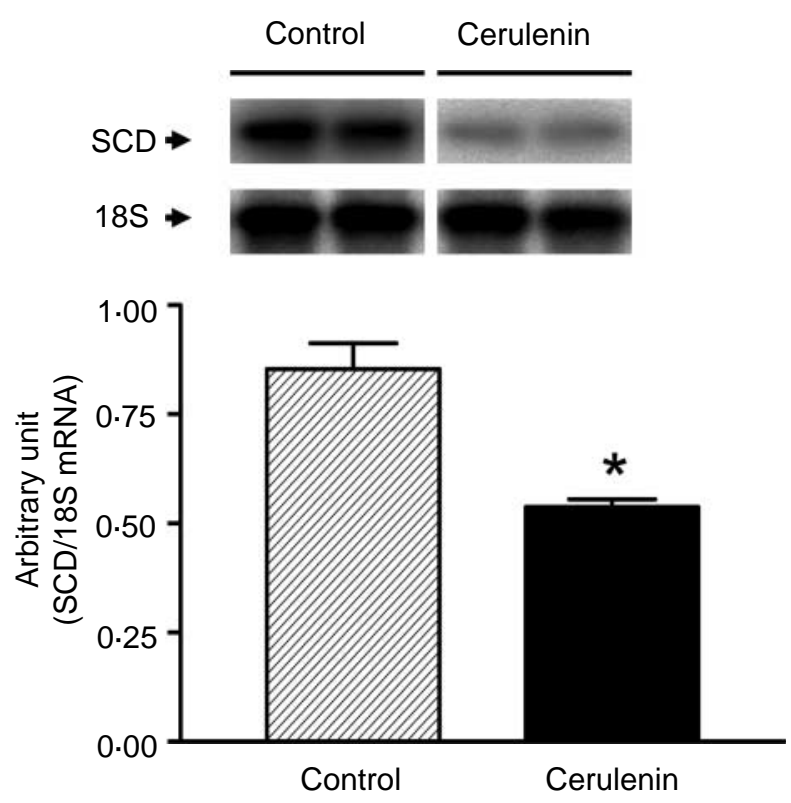

Figure 3 Effect of cerulenin administration on SCD gene expression in muscle of 2-week-old broiler chickens. Values are means \pm s.E.M., $n=4$. *Different from the control, $P<0 \cdot 05$.

thyroid hormones (Waters et al. 1997, Ameen et al. 2004), might explain the tissue-specific and sex-dependent expression of avian SCD (Kuhn et al. 1996, Richards et al. 2000, Liu et al. 2002).

Recent reports have clearly shown that SCD-1 is involved, at least partly, in the effect of leptin on energy expenditure and body weight (Cohen et al. 2002, Cohen \& Friedman 2004). Leptin was found to reduce adiposity and liver triglyceride content in part by reducing SCD-1 mRNA and enzymatic activity in liver (Cohen et al. 2002). Such exciting data, which are currently lacking in non-mammalian species, prompted us to investigate the regulatory effects of leptin on $S C D$ gene expression in three metabolically important tissues, namely the liver (the main site of lipogenesis (Leveille et al. 1968)), the hypothalamus (the site of food intake and energy homeostasis control (Robinzon et al. 1975, Denbow 1985)), and the muscle (the main site of thermogenesis (Duchamp \& Barré 1993)).

The biological activity of the recombinant chicken leptin was demonstrated previously by its ability to stimulate the proliferation of BAF3 cells in vitro, transfected with the functional long form of the human leptin receptor (ob-Rb), and in vivo by its inhibitory effect on food intake after a single injection (Raver et al. 1998, Dridi et al. 2000b). In the present study, recombinant chicken leptin administered continuously increased plasma leptin levels and inhibited food intake. Surprisingly, despite the decrease in food intake, leptin significantly increases SCD gene expression in chicken liver, but not in hypothalamus or muscle. These results indicate that leptin regulates $S C D$ gene expression in a tissue-specific manner. 

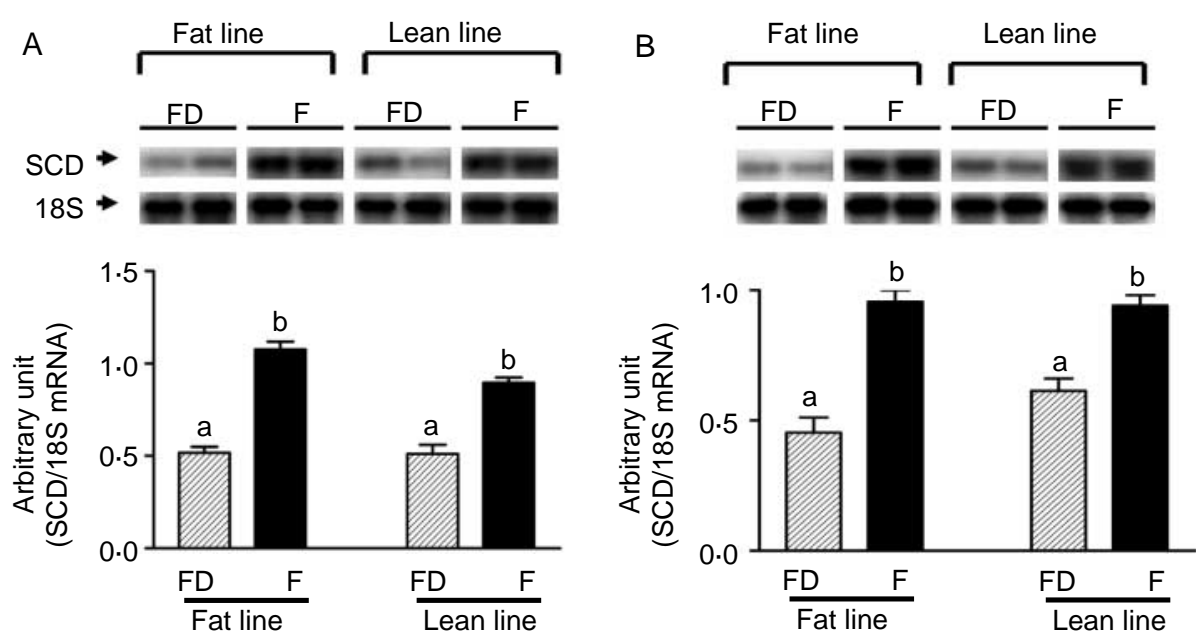

Figure 4 Effect of (A) 16 or (B) $24 \mathrm{~h}$ food deprivation on hepatic SCD gene expression in genetically fat and lean line chickens. Values are means \pm S.E.M., $n=3$. Superscript letters indicate a significant difference at $P<0 \cdot 05$. Genotype effect (G), $P>0 \cdot 05$; nutritional state effect (NS), $P<0 \cdot 05$; interaction $(\mathrm{G} \times \mathrm{NS}), P>0 \cdot 05$. F, fed; FD, food deprived.

The absence of leptin's effect on hypothalamic and muscle $S C D$ gene expression should be interpreted cautiously because other specific SCD isoforms, that are not yet known, may exist and may be affected by leptin as previously reported for mammalian heart SCD-4 (Miyazaki et al. 2003). In addition, in our study, we measured only RNA levels and leptin may affect the enzymatic activity differently as previously reported for mammals (Miyazaki et al. 2003).

Leptin seems to have an opposite effect on chicken hepatic $S C D$ gene expression compared with that described in mammals (Cohen et al. 2002). The mechanisms behind this difference are unclear and may be related to many factors such as dose and time of leptin treatment and species-specific effects. It has been shown that leptin exerts a dose-dependent biphasic effect on mammalian steroidogenesis (Ruiz-Cortes et al. 2003) and corticosterone secretion (Malendowicz et al. 2004). In mammals, leptin is mainly expressed in adipose tissue (Zhang et al. 1994) and its effects on hepatic SCD-1 are probably mediated by central action (Cohen et al. 2002). In birds, leptin is expressed not only in adipose tissue, but also in liver (Taouis et al. 1998, Ashwell et al. 1999), which is the major source for leptin (Richards et al. 1999). Although leptin inhibits the expression of its receptor in liver and hypothalamus (Dridi et al. 2005a,b), the specific mechanism by which leptin induces $S C D$ gene expression in chicken liver is presently unknown and further studies are warranted.

Although leptin has long been known to play roles in the regulation of food intake and energy homeostasis, the potential role of fatty acid metabolism in this process has been considered only recently. Inhibition of fatty acid synthesis by cerulenin reduces food intake and induces profound reversible weight loss (Loftus et al. 2000). Centrally, this compound was hypothesized to alter, like leptin, the expression profiles of feeding-related neuropeptides, often inhibiting the orexigenic and inducing the anorexigenic neuropeptide gene expression (Shimokawa et al. 2002). We have recently shown that cerulenin inhibits food intake by altering, like leptin, the expression of melanocortin receptors, but without modulating the other known neuropeptides that are involved in food intake regulation (Dridi et al. 2006). Therefore, we sought to assess in this study whether cerulenin
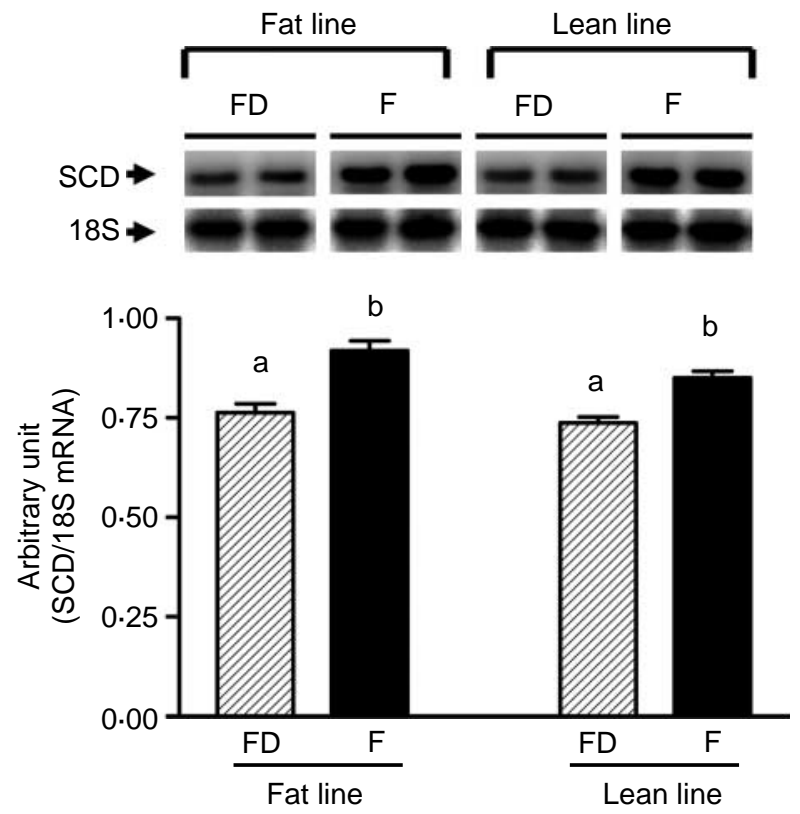

Figure 5 Effect of food deprivation ( $24 \mathrm{~h}$ ) on hypothalamic SCD gene expression in genetically fat and lean line chickens. Values are means \pm S.E.M., $n=3$. Superscript letters indicate a significant difference at $P<0 \cdot 05$. Genotype effect (G), $P>0 \cdot 05$; nutritional state effect (NS), $P<0 \cdot 01$; interaction $(\mathrm{G} \times \mathrm{NS}), P>0 \cdot 05$. F, fed; FD, food deprived. 
affects, like leptin, SCD gene expression. Our data showed that cerulenin administration reduces food intake and decreases SCD mRNA levels in chicken muscle. However, the hepatic and hypothalamic SCD gene expression was not affected by cerulenin treatment. This result supports again the tissue-specific regulation of SCD and suggests that leptin and cerulenin may regulate $S C D$ gene expression via different pathways.

Many developmental, dietary, hormonal, and environmental factors regulate SCD-1 gene expression (Miyazaki \& Ntambi 2003). We ascertain in the present study whether SCD mRNA levels differ between tissues in response to starvation and abdominal fat pad size of FL and LL chickens. The expression of SCD is reduced by either 16 or $24 \mathrm{~h}$ food deprivation in chicken liver, but not in muscle. Furthermore, food deprivation for $24 \mathrm{~h}$, but not for $16 \mathrm{~h}$, downregulates SCD mRNA levels in chicken hypothalamus. These data indicate that the sensitivity of SCD gene to food deprivation varied among tissues, with the highest sensitivity in the liver. The mechanism behind the time-lag between tissues is still unknown. The repression of $S C D$ gene expression in the hypothalamus by food deprivation suggests that hypothalamic SCD responds to feeding status and may be involved in the regulation of food intake in chickens as previously described in mammals (Ntambi et al. 2002, Dobrzyn \& Ntambi 2004, Guoqiang et al. 2005). Regardless of the nutritional state, SCD mRNA levels did not differ between FL and LL chickens. This result is concordant with the previous finding concerning hepatic SCD mRNA (Daval et al. 2000). However, previous studies have shown that hepatic SCD activity was significantly higher in FL than in LL chickens (Legrand et al. 1987, Legrand \& Hermier 1992). Furthermore, the proportion of palmitoleic acid which results from hepatic $\Delta 9$ desaturation was higher in FL compared with LL chickens (Legrand \& Hermier 1992) and a positive correlation has been found between SCD mRNA levels and fatness in vivo (Douaire et al. 1992). We have recently shown that circulating leptin levels and hepatic leptin gene expression were significantly higher in FL compared with LL chickens (Dridi et al. 2005b). These observations in combination with the present data suggest that the interaction of leptin with SCD may be crucial in the regulation of avian hepatic lipogenesis.

In conclusion, the present study is the first to report the regulation of $S C D$ gene expression in different metabolically important tissues by leptin, cerulenin, nutritional state, and gender. These factors regulate the expression of SCD gene in a tissue-selective manner. In contrast to mammals, leptin induces $S C D$ gene expression in chicken liver, suggesting subtle species-dependent differences in the role of leptin at least in this tissue. Cerulenin inhibits $S C D$ gene expression in muscle; however, food deprivation decreases $S C D$ gene expression in both liver and hypothalamus of chickens and this effect was observed with a time-lag between tissues. The tissue-specific and sex-dependent expression of SCD suggests the presence of complex hormone-specific control mechanisms.

\section{Acknowledgements}

We thank Dr Anne Collin (INRA Tours, France) for providing the FL and LL chickens.

\section{Funding}

This work was supported by research grant (G.0402.05) from the FWO-Flanders (Belgium). There is no conflict of interest that would prejudice impartiality.

\section{References}

Ameen C, Linden D, Larsson BM, Mode A, Holmang A \& Oscarsson J 2004 Effects of gender and GH secretory pattern on sterol regulatory elementbinding protein-1c and its target genes in rat liver. American Journal of Physiology 287 E1039-E1048.

Ashwell CM, Czerwinski SM, Brocht DM \& McMurtry JP 1999 Hormonal regulation of leptin expression in broiler chickens. American Journal of Physiology 276 R226-R232.

Blair SC, Cooney GJ, Denyer GS, Williams PF \& Caterson ID 1991 Differences in lipogenesis in tissues of control and gold-thioglucose obese mice after an isocaloric meal. Biochimica et Biophysica Acta 1085 385-388.

Chung M, Ha S, Jeong S, Bok J, Cho K, Baik M \& Choi Y 2000 Cloning and characterization of bovine stearoyl-CoA desaturase $1 \mathrm{cDNA}$ from adipose tissue. Bioscience Biotechnology and Biochemistry 64 1526-1530.

Cohen P \& Friedman JM 2004 Leptin and the control of metabolism: role for stearoyl-CoA desaturase-1 (SCD-1). Journal of Nutrition 1342455 S-2463S.

Cohen P, Miyazaki M, Socci ND, Hagge-Greenberg A, Liedtke W, Soukas AA, Sharma R, Hudgins LC, Ntambi JM \& Friedman JM 2002 Role of stearoylCoA desaturase-1 in leptin-mediated weight loss. Science 297 240-243.

Dashti N, Kelley JL, Thayer RH \& Ontko JA 1983 Concurrent inductions of avian hepatic lipogenesis, plasma lipids, and plama apolipoprotein B by estrogen. Journal of Lipid Research 24 368-380.

Daval S, Lagarrigue S \& Donaire M 2000 Messenger RNA levels and transcription rates of hepatic lipogenesis genes in genetically lean and fat chickens. Genetics Selection Evolution 32 521-531.

Denbow DM 1985 Food intake control in birds. Neuroscience and Biobehavioral Reviews 9 223-232.

Dobrzyn A \& Ntambi JM 2004 The role of stearoyl-CoA desaturase in body weight regulation. Trends in Cardiovascular Medicine 14 77-81.

Douaire M, Le Fur N, Elkhadir-Mounier C, Langlois P, Flamant F \& Mallard J 1992 Identifying genes involved in the variability of genetic fatness in the growing chicken. Poultry Science 71 1911-1920.

Dridi S, Williams J, Bruggeman V, Onagbesan M, Raver N, Decuypere E, Djiane J, Gertler A \& Taouis M 2000a A chicken leptin-specific radioimmunoassay. Domestic Animal Endocrinology 18 325-335.

Dridi S, Raver N, Gussakovsky EE, Derouet M, Picard M, Gertler A \& Taouis M $2000 \mathrm{~b}$ Biological activities of recombinant chicken leptin C4S analog compared with unmodified leptons. American Journal of Physiology 279 E116-E123.

Dridi S, Swennen Q, Decuypere E \& Buyse J 2005a Mode of leptin action in chicken hypothalamus. Brain Research 1047 214-223.

Dridi S, Buyse J, Decuypere E \& Taouis M 2005b Potential role of leptin in increase of fatty acid synthase gene expression in chicken liver. Domestic Animal Endocrinology 29 646-660.

Dridi S, Ververken C, Hillgartner FB, Arckens L, Van der Gucht E, Cnops L, Decuypere E \& Buyse J 2006 FAS inhibitor cerulenin reduces food intake and melanocortin receptor gene expression without modulating the other (an)orexigenic neuropeptides in chickens. American Journal of Physiology 291 R138-R 147.

Duchamp C \& Barré H 1993 Skeletal muscle as the major site of nonshivering thermogenesis in cold-acclimated duckling. American Journal of Physiology 265 R10176-R10183. 
Enoch HG, Catala A \& Strittmatter P 1976 Mechanism of rat liver microsomal stearoyl-CoA desaturase. Studies of the substrate specificity, enzymesubstrate interactions, and the function of lipid. Journal of Biological Chemistry $2515095-5103$.

Feinberg AP \& Vogelstein BA 1983 Technique for radiolabeling DNA restriction endonuclease fragments to high specific activity. Analytical Biochemistry 132 6-13.

Griffin HD \& Goddard C 1994 Rapidly growing broiler (meat-type) chickens: their origin and use for comparative studies of the regulation of growth. International Journal of Biochemistry 26 19-28.

Guoqiang J, Li Z, Liu F, Ellsworth K, Dallas-Yang Q, Wu M, Ronan J, Esau C, Murphy C, Szalkowski D et al. 2005 Prevention of obesity in mice by antisense oligonucleotide inhibitors of stearoyl-CoA desaturase-1. Journal of Clinical Investigation 115 1030-1038.

Heineman FS \& Ozols J 2003 Stearoyl-CoA desaturase, a short lived protein of endoplasmic reticulum with multiple control mechanisms. Prostaglandins Leukotrienes and Essential Fatty Acids 68 122-133.

Huybrechts LM, Decuypere E, Buyse J, Kuhn ER \& Tixier-Boichard M 1992 Effect of recombinant human insulin-like growth factor-1 on weight gain, fat content, and hormonal parameters in broiler chickens. Poultry Science $\mathbf{7 1}$ 181-187.

Kaestner KH, Ntambi JM, Kelly TJJ \& Lane DM 1989 Differentiationinduced gene expression in 3T3-L1 preadipocytes. A second differentially expressed gene encoding stearoyl-CoA desaturase. Journal of Biological Chemistry 264 14755-14761.

Kawashima Y, Uy-Yu N \& Kozuka H 1989 Sex-related differences in the enhancing effects of perfluoro-octanoic acid on steroyl-CoA desaturase and its influence on the acyl composition of phospholipid in rat liver. Comparison with clofibric acid and tiadenol. Biochemical Journal 263 897-904.

Kuhn ER, Darras VM, Gysemans C, Decuypere E, Berghman LR \& Buyse J 1996 The use of intermittent lighting in broiler raising. 2. Effects on the somatotrophic and thyroid axes and on plasma testosterone levels. Poultry Science 75 595-600.

Leclercq B, Blum JC \& Boyer JP 1980 Selecting broilers for low or high abdominal fat: initial observations. British Poultry Science 21 107-113.

Lee KN, Pariza MW \& Ntambi JM 1996 Differential expression of hepatic stearoyl-CoA desaturase gene 1 in male and female mice. Biochimica et Biophysica Acta 1304 85-88.

Lefevre P, Diot C, Legrand P \& Douaire M 1999 Hormonal regulation of stearoyl coenzyme-A desaturase 1 activity and gene expression in primary cultures of chicken hepatocytes. Archives of Biochemistry and Biophysics 368 329-337.

Lefevre P, Tripon E, Plumelet C, Douaire M \& Diot C 2001 Effects of polyunsaturated fatty acids and clofibrate on chicken stearoyl-CoA desaturase 1 gene expression. Biochemical and Biophysical Research Communications $28025-31$

Legrand P \& Hermier D 1992 Hepatic delta 9 desaturation and plasma VLDL level in genetically lean and fat chickens. International Journal of Obesity and Related Metabolic Disorders 16 289-294.

Legrand P, Mallard J, Bernard-Griffiths MA, Douaire M \& Lemarchal P 1987 Hepatic lipogenesis in genetically lean and fat chickens. In vitro studies. Comparative Biochemistry and Physiology 87 789-792.

Leveille GA, O'Hea EK \& Chakrabarty K 1968 In vivo lipogenesis in the domestic chicken. Proceedings of the Society for Experimental Biology and Medicine 128 398-401.

Lippiello PM, Holloway CT, Garfield SA \& Holloway PW 1979 The effects of estradiol on stearoyl-CoA desaturase activity and microsomal membrane properties in rooster liver. Journal of Biological Chemistry 254 2004-2009.

Liu YL, Yakar S, Otero-Corchon Y, Low MJ \& Liu JL 2002 Ghrelin gene expression is age-dependent and influenced by gender and the level of circulating IGF-I. Molecular and Cellular Endocrinology 189 97-103.

Loftus TM, Jaworsky DE, Frehywot GL, Townsend CA, Ronnett GV, Lane MD \& Kuhajda FP 2000 Reduced food intake and body weight in mice treated with fatty acid synthase inhibitors. Science 288 2379-2381.

Malendowicz LK, Spinazzi R, Tortorella C, Nussdorfer GG, Ziolkowska A \& Rucinski M 2004 Effect of leptin and leptin fragments on corticosterone secretion and growth of cultured rat adrenocortical cells. International Journal of Molecular Medicine 14 873-877.
Mihara K 1990 Structure and regulation of rat liver microsomal stearoyl-CoA desaturase gene. Biochemical Journal 108 1022-1029.

Miyazaki M \& Ntambi JM 2003 Role of stearoyl-coenzyme A desaturase in lipid metabolism. Prostaglandins, Leukotrienes and Essential Fatty Acids 68 113-121.

Miyazaki M, Jacobson MJ, Man WC, Cohen P, Asilmaz E, Friedman JM \& Ntambi JM 2003 Identification and characterization of murine SCD4, a novel heart-specific stearoyl-CoA desaturase isoform regulated by leptin and dietary factors. Journal of Biological Chemistry 278 33904-33911.

Ntambi JM, Buhrow SA, Kaestner KH, Christy RJ, Sibley E, Kelly TJJ \& Lane MD 1988 Differentiation-induced gene expression in 3T3-L1 preadipocytes. Characterization of a differentially expressed gene encoding stearoyl-CoA desaturase. Journal of Biological Chemistry 263 17291-17300.

Ntambi JM, Miyazaki M, Stoehr JP, Lan H, Kendziorski CM, Yundell BS, Song Y, Cohen P, Friedman JM \& Attie AD 2002 Loss of stearoyl-CoA desaturase-1 function protects mice against adiposity. PNAS $\mathbf{9 9}$ $11482-11486$.

Raver N, Taouis M, Dridi S, Derouet M, Simon J, Robinzon B, Djiane J \& Gertler A 1998 Large-scale preparation of biologically active recombinant chicken obese protein (leptin). Protein Expression and Purification 14 403-408.

Richards MP, Ashwell MC \& McMurtry JP 1999 Analysis of leptin gene expression in chicken using reverse transcription polymerase chain reaction and capillary electrophoresis with laser-induced fluorescence detection. Journal of Chromatography A 853 321-335.

Richards MP, Ashwell CM \& McMurtry JP 2000 Quantitative analysis of leptin mRNA using competitive reverse transcription polymerase chain reaction and capillary electrophoresis with laser-induced fluorescence detection. Electrophoresis 21 792-798.

Robinzon B, Snapir N \& Perek M 1975 The relation between monosodium glutamate inducing brain damage, and body weight, food intake, semen production and endocrine criteria in the fowl. Poultry Science 54 234-241.

Ruiz-Cortes ZT, Martel-Kennes Y, Gevry NY, Downey BR, Palin MF \& Murphy BD 2003 Biphasic effects of leptin in porcine granulosa cells. Biology of Reproduction 68 789-796.

Shimokawa T, Kumar MV \& Lane MD 2002 Effect of fatty acid synthase inhibitor on food intake and expression of hypothalamic neuropeptides. PNAS 99 66-71.

Taouis M, Chen JW, Daviaud C, Dupont J, Derouet M \& Simon J 1998 Cloning the chicken leptin gene. Gene 208 239-242.

Theander-Carrillo C, Wiedmer P, Cettour-Rose P, Nogueiras R, Perez-Tilve D, Pfluger P, Castaneda TR, Muzzin P, Schürmann A, Szanto L et al. 2006 Ghrelin action in the brain controls adipocyte metabolism. Journal of Clinical Investigation 116 1983-1993.

Wang J, Yu L, Schmidt RE, Su C, Huang X, Gould K \& Cao G 2005 Characterization of HSCD5, a novel human stearoyl-CoA desaturase unique to primates. Biochemical and Biophysical Research Communications 332 735-742.

Waters KM, Miller CW \& Ntambi JM 1997 Localization of a negative thyroid hormone-response region in hepatic steroyl-CoA desaturase gene 1. Biochemical and Biophysical Research Communications 233 838-843.

Zhang Y, Proenca R, Maffei M, Barone M, Leopold L \& Friedman JM 1994 Positional cloning of the mouse obese gene and its human homologue. Nature 372 425-432.

Zhang L, Ge L, Parimoo S, Stenn K \& Prouty SM 1999 Human stearoyl-CoA desaturase: alternative transcripts generated from a single gene by usage of tandem polyadenylation sites. Biochemical Journal 340 255-264.

Zheng Y, Eilertsen KJ, Ge L, Zhang L, Sundberg JP, Prouty SM, Stenn S \& Parimoo KS 1999 SCD-1 is expressed in sebaceous glands and is disrupted in the asebia mouse. Nature Genetics 23 268-270.

Zheng Y, Prouty SM, Harmon A, Sundberg JP, Stenn KS \& Parimoo S 2001 SCD-3 a novel gene of the stearoyl-CoA desaturase family with restricted expression in skin. Genomics 71 182-191.

\section{Received in final form 6 October 2006 \\ Accepted 14 October 2006 \\ Made available online as an Accepted Preprint 17 October 2006}

